Magnus Oscarsson is teacher educator at Mid Sweden University in Härnösand and graduate student at the Swedish national graduate school in science and technology education research (FontD). He has carried out the ROSE study in Sweden, is national project manager for OECD/PISA and science manager for TIMSS 2011 in Sweden.

Karl-Göran Karlsson is associated Professor in science education at Mid Sweden University, and science manager for OECD/PISA in Sweden.

MAGNUS OSKARSSON

Mid Sweden University

magnus.oskarsson@miun.se

KARL-GÖRAN KARLSSON

Mid Sweden University

kg.karlsson@miun.se

\title{
Health care or Atom bombs? Interest profiles connected to a science career in Sweden
}

\begin{abstract}
The ROSE survey explores which science topics 15-year-old students want to study. By carrying out a factor analysis on results from Sweden it was possible to describe ten interest profiles. The interest profile with the strongest connection to the students' interest in school science consists of topics such as explosive chemicals, $A B C$ weapons, electric shocks, atoms and molecules. Only a minority of the students has these interests, but it is this minority who appreciates school science and who chooses to study science at upper secondary school. The factor analysis also reveals large differences between genders and furthermore, that the students' own interests govern their choice of study programme at upper secondary school.
\end{abstract}

\section{BACKGROUND}

Students' attitudes to science and technology have increasingly gained greater attention over the last decade. Fewer young people are choosing science as a career in many countries (Osborne, Simon, \& Collins, 2003) A study in Sweden in the early 90s indicated that as many as 75 percent of the students assumed to have the capability to study science did not do so. Students felt that particularly mathematics at lower secondary level was difficult and boring (Skolverket, 1994, 1995).

In the last decades great efforts have been made to increase recruitment to science and technology. Nevertheless, the proportion of Swedish students choosing science at upper secondary school has remained stable. The last 15 years somewhere between 18 and 22 percent of students from compulsory school have chosen either a science or technology programme (Skolverket, 2007).

\section{Science in society or science in school}

Jidesjö, Oscarsson, Karlsson and Strömdahl (2009) show that there is considerable interest in many general science topics among 15-year-old boys and girls in Sweden. Students want to learn more about what to eat and how to exercise to keep the body healthy and fit. They are also inter- 
ested in alcohol, narcotics and tobacco and how these affect the body, as well as why we dream when we sleep and what dreams may mean. Students are not interested in topics like atoms and molecules, plants in their local environment, optical instruments, detergents, plastics or lotions and creams. Results from the ROSE survey in England and Norway show the same picture (Jenkins \& Nelson, 2005; Schreiner, 2005). It is hard to see any clear differences between students' interest in various science subjects. Students are interested in some topics from Biology as well as topics from Physics and Chemistry, while other topics from these subjects are at the very bottom of students' interest lists. Students are also asked both about scientific concepts and different applications. There is a lack of interest for optics and acoustics as well as for the rainbow and how sound is produced in musical instruments (Schreiner \& Sjöberg, 2004) . Students find school science less interesting than other subjects (Lindahl, 2003). In fact, school science in Sweden seems appealing only to a minority of students and it is mainly from this minority recruitment to science is made (Jidesjö, et al., 2009).

It seems to be a disparity between what teachers teach and what their students want to learn. Teachers focus on facts like atoms and molecules, electricity, the eye and the ear while students are interested in health care, space or unsolved problems in science or society. (Oscarsson, Jidesjö, Karlsson, \& Strömdahl, 2009).

According to a recent survey, 58 percent of upper secondary school students report that school does not increase their interest in research or science (Gunnarsson, 2009). However, in contrast to school science, several popular television programmes such as Mythbusters, CSI, House and Grey's Anatomy stimulate a great deal of interest in scientific topics. The majority of students have favourite programs promoting increased interest in science while only 14 percent of the students state that television does not increase their interest in science (ibid.).

\section{Interest in science}

Students' interest is science is here defined as a subjective interest. The focus is on students own interest in science topics, their opinions about science, attitudes to school science and career ambitions.

Schreiner (2005) has analysed the Norwegian ROSE survey and explored five different student types. The unselective enthusiast: A student type committed to school who is interested in most subjects, positive to school and teachers and who plans to take an advanced education. The unselective reluctant: A student type who is aloof and unwilling and who has a negative attitude towards science in particular and school in general. The unselective undecided: This student type is ambivalent to both school and science. The selective boy: A student who is self-expressive with critical and conscious attitudes, with discriminating preferences, interests in school science and in traditionally masculine topics. The selective girl: She is similar to the previous boy having critical and conscious attitudes, discriminating preferences, and with interests in traditionally female topics.

Schreiner explores how these types relate to and get into conflict with science and school science in modern society. Students are concerned about the negative features of science and are aware of the environment. Science is considered important for society by most of the student types but not important for themselves personally.

Furthermore, ROSE-data from around the world reveals a transnational pattern in relation to modernization. The more modernized a country is, the lower the interest in school science and the stronger the gender differences (Schreiner, 2005). The OECD/PISA study also shows a pattern where countries with high socioeconomic indices and good results on the cognitive test tend to have lower scores on the interest scale. This is the case when comparing different countries with each other. Nevertheless, there is a positive relationship between the cognitive and the attitudinal 
scale within most countries, meaning that a good performing student is also an interested student or vice versa. In each country, there is also a positive relationship between students' socioeconomic background and their science score. In Sweden, however, the relationship between interest and socioeconomic background is weak (OECD, 2007).

\section{Interest and identity}

To understand the lack of interest in school science shown by students in Sweden and many other countries it is necessary to look at the formation of identity. Adolescence is a time of identity construction. In modern society, the flow of information is greater than ever and there are more alternatives to consider in the construction of identity. Giddens (1991) describes the weakened role of tradition and authority in this process. There is greater freedom to choose and more alternatives than previously. The formation of self-identity is an ongoing endeavour, a reflexive project that we continuously work and reflect upon. Who we are and who we will become creates a story about ourselves. Modern society offers hope of emancipation but at the same time we see growing differences and marginalisation (ibid.). Bourdieu describes how society is divided by economic, social and cultural capital. Style, taste, how you dress, language, who you associate with, all construct a different habitus available to the individual in society (Bourdieu, 1993). In this sense, it is not just about what you as an individual want to become, instead it is about to whom you belong and to whom you want to belong.

Students' interest is in this sense, not a free choice. There exists alternatives but the group constrains are strong.

\section{Identity and gender}

If identity making is choosing where to belong, gender becomes important. Gender is a good illustration of the absence of a real freedom of choice, not only in the biological sense. The social construction of different gender roles becomes obvious during adolescence. Male and female are still the main archetypes between which we have to choose. The entire youth culture is impregnated with different roles for boys and girls. It is so incorporated in our culture that it is very hard to overcome even if we recognize it. Gender in this sense is about doing, not about being (Smedler \& Drake, 2006). How we talk, how we dress, how we act etc. is about making gender in real life as a part of our identity making. Butler (1999) describes this dichotomy as a heterosexual matrix. In the young person's liberation from the family, the rules of the peer group become more important than the rules of the family. Ambjörnsson (2004) describes how upper secondary girls struggle to become a 'proper' girl: not too much make up and not too little, hair and body of the right shape; the overall appearance has to give the right signals. It is however an ambiguous picture. The Nordic countries are regarded as having great gender equality. In the latest global gender gap report Sweden, Norway, Finland and Iceland are the countries with the highest gender equality. Women in these countries have better opportunities in education and politics and better economical opportunities. The equality score is also increasing, driven mainly by a decreasing gap between women's and men's labour force participation rates and salaries (Hausmann, Tyson, \& Zahidi, 2010)

\section{Which students choose science?}

It was difficult to see any clear pattern in students' interest in different science subjects or interests for topics placed in different contexts in the first analysis of data from the ROSE survey (Jidesjö, et al., 2009). It seems necessary to dig deeper into the material in search for patterns that might explain the low interest in school science (Skolverket, 2004). Is it possible to find constructs that group different topics in the questionnaire better than just different subjects or different context? Is it possible to explain students' choice of upper secondary programme from these constructs? 
Almost all Swedish students continue on one of the 17 national three-year programmes in upper secondary school. All programmes offer a broad general education and basic eligibility to study at post-secondary level. Two programmes are dominated by science and technology: the Science programme and the Technology programme. There are also several vocational programmes oriented towards engineering, industry and health (The Swedish National Agency for Education, 2007). Boys dominate vocational programmes oriented towards industry and girls dominate vocational programmes with an orientation to health and the service sector. The Science programme is an exception and has the smallest gender difference. The science programme has high status and is chosen by both boys and girls. The difference in these students' interests and career ambitions can nevertheless be seen when they apply for university. A programme like bio-medicine have more than $80 \%$ percent girls while the engineering programmes only attract $25 \%$ girls on average (SOU, 2010).

\section{Research questions}

How does interest in different science topics reflect choice of study programme at upper secondary school?

Which interest profiles distinguish future science students from other students?

\section{METHODOLOGY}

\section{Rose questionnaire}

By means of a questionnaire about attitudes to science and technology, the ROSE project aims to capture aspects of 15-year-old students' interest in science education (Schreiner \& Sjöberg, 2004). About 40 countries from all continents are involved in the ROSE survey (ROSE 2011). The Swedish ROSE study received data from 29 schools with a total sample of 751 students (Oscarsson \& Jidesjö, 2005).

The first part of the ROSE questionnaire asks about the students' interest in learning about 108 different science topics. The topics in the questionnaire are from different science subjects and the topics are placed in different contexts. The students answered on a four-grade Likert-scale ranging from Not interested (value 1) to Very interested (value 4). Another part of the questionnaire asked about students' opinion of their science classes (Schreiner \& Sjöberg, 2004).

\section{Factor analysis}

In this study we conducted an explorative factor analysis in SPSS aiming to find factors that characterise different student interests and preferences. A correlation between two variables does not imply causality. Often a third variable explains the relationship between the two variables. Factor analysis is widely used to find underlying latent variables that could explain such relationships (Brace, Kemp, \& Snelgar, 2006). A large sample with many questions about people's views or interests often reveals patterns of correlation because several of the questions measure the same position or attitude. An explorative factor analysis builds constructs that reveal these underlying variables (Tabachnick \& Fidell, 2001).

In the factor analysis it was necessary to have answers to all the 108 questions in the questionnaire. 148 students had some missing values, hence, these are excluded from the present analysis and the analysis is based on 603 complete questionnaires.

First an initial solution is made followed by a varimax rotation. In the space that all answers create, the rotation searches for a pattern with high correlation between topics connected to each factor and low correlation between the factors. Next step is the extraction where all questions (topics) get a loading for each factor that explains to what extent the factor can explain the variance in the 
students' answers to that specific question. The factors with the highest sum of square loadings are identified. In the last step each student gets a score for each factor that tells us how close that student's answers are connected with this factor. The scores are standardised with a zero mean and a standard deviation of one. Then it is possible to see the relation between factor scores i.e. students interest profiles, gender and choice of upper secondary programme.

\section{Validity}

To investigate the validity of the factor analysis it is necessary to search for high correlation between variables with high loading for each factor and low correlation between variables with high loading for different factors. Kaiser-Meyer-Olkin measure of sampling adequacy (KMO) is a ratio of the sum of squared correlations between the variables to the sum of squared correlations plus the sum of partial correlations. The KMO value for the factor analysis described in this article is 0.951 and this is well above what is required (Kaiser, 1974). Cronbach's alpha ( $\alpha)$ is a measure of how closely related a set of items is as a group i.e. internal consistency. $\alpha$ is calculated for the topics with highest loading on each factor (Cronbach, 1990). As a rule of thumb a should be over 0.7 (Brace, et al., 2006). $\alpha$ for the 10 factors in this analysis vary between 0.76 and 0.92 . The $\alpha$ and KMO values ensure a good validity in the factor analysis and indicate that it is fair to regard each factor as a latent variable, that is a variable that is not directly observed but derived from other observed variables.

\section{RESULTS}

After the rotation 18 factors with loadings over 1 were found. The sum of the square loadings tells us to what extent the factor explains the variance of the answers to these 108 questions. All 18 factors explain 66 percent of the variance. It is not enough space here to describe all factors, so we pursue the 10 factors with highest loading, see table 1 . These 10 factors explain in total 53 percent of the variance.

Table 1. SPSS table with factor loadings for the rotated solution.

\begin{tabular}{|c|c|c|c|}
\hline \multirow{2}{*}{ Component } & \multicolumn{3}{|c|}{$\begin{array}{c}\text { Rotation Sums } \\
\text { of Squared Loadings }\end{array}$} \\
\hline (Factor) & Total & $\begin{array}{c}\text { percent of } \\
\text { Variance }\end{array}$ & cumulative percent \\
\hline 1 & 11.09 & 10.27 & 10.27 \\
\hline 2 & 7.76 & 7.19 & 17.46 \\
\hline 3 & 7.35 & 6.81 & 24.27 \\
\hline 4 & 7.09 & 6.57 & 30.84 \\
\hline 5 & 6.37 & 5.90 & 36.74 \\
\hline 6 & 4.70 & 4.35 & 41.09 \\
\hline 7 & 3.81 & 3.53 & 44.62 \\
\hline 8 & 3.41 & 3.16 & 47.78 \\
\hline 9 & 3.35 & 3.10 & 50.88 \\
\hline 10 & 2.51 & 2.32 & 53.20 \\
\hline
\end{tabular}


Table 2 contains the topics with the highest loading for the ten factors. As a rule loadings over 0.32 are usually investigated (Tabachnick \& Fidell, 2001). It is not possible to show all topics with a factor loading over 0.32 so only enough topics to illustrate each factor are presented. Each factor is named in italics to illustrate the area of interest it represents. When extracting the ten factors described above, it is easy to find a connection between the topics with high loading for each factor, see table 2. The Sum of Square Loading (SSL) as a percentage of the variance for each factor is also given.

Table 2 Ten factors with high loading topics.

Factor 1 Health (SSL= 10.27 percent $\alpha=0.929)$ all loadings over 0.6

What we know about HIVIAIDS and how to control it

loading

Cancer, what we know and how we can treat it

0.79

0.77

0.76

Sexually transmitted diseases and how to be protected against them

0.71

Biological and human aspects of abortion

0.69

0.67

Birth control and contraception

0.65

How to perform first-aid and use basic medical equipment

0.65

How babies grow and mature

0.65

How different narcotics might affect the body

0.63

0.63

0.63

0.64

How gene technology can prevent diseases

loading

0.73

0.73

0.69

0.67

0.64

0.63

0.63

0.56

0.53

0.50

0.50

The use of satellites for communication and other purposes

loading

Factor 3 Risk (SSL= 6.81 percent $\alpha=0.903$ ) all loadings over 0.5

0.78

Explosive chemicals

0.72

0.69

0.66

0.65

0.64

0.61

0.58

0.55 
Factor 4 Environment (SSL 6.66 percent, $\alpha=0.885$ ) all loadings over 0.5

loading

Organic and ecological farming without use of pesticides and artificial fertilizers

0.74

Benefits and possible hazards of modern methods of farming

0.71

How to improve the harvest in gardens and farms

0.69

Plants in my area

0.64

How different sorts of food are produced, conserved and stored

0.61

Medicinal use of plants

0.60

How energy can be saved or used in a more effective way

0.58

Risks and benefits of food additives

0.57

New sources of energy from the sun, wind, tides, waves, etc.

0.55

Factor 5 Technology (SSL= 5.99 percent, $\alpha=0.888$ ) all loadings over 0.5

loading

How cassette tapes, CDs and DVDs store and play sound and music

0.80

How things like radios and televisions work

0.80

How mobile phones can send and receive messages

0.76

The use of lasers for technical purposes (CD-players, bar-code readers, etc.)

0.74

How computers work

0.71

Electricity, how it is produced and used in the home

0.56

How to use and repair everyday electrical and mecanical equipment

0.53

Optical instruments and how they work (telescope, camera, microscope, etc.)

0.50

Factor 6 New Age (SSL= 4.35 percent, $\alpha=0.860$ ) all loadings over 0.5

Thought transference, mind-reading, sixth sense, intuition, etc.

loading

Ghosts and witches, and whether they may exist

0.80

0.76

Why we dream while we are sleeping, and what the dreams may mean

0.70

Astrology and horoscopes, and whether the planets can influence human beings

0.59

Life and death and the human soul

0.58

Alternative therapies (acupuncture, homeopathy, yoga, healing, etc.) and how effective they are

0.57

Factor 7 Philosophy of Science (SSL= 3.53 percent, $\alpha=0.835$ ) all loadings over 0.5

How scientific ideas sometimes challenge religion, authority and tradition

0.67

Famous scientists and their lives

0.61

Big blunders and mistakes in research and inventions

0.60

Inventions and discoveries that have changed the world

0.58

Why scientists sometimes disagree

0.57

Why religion and science sometimes are in conflict

0.57

Factor 8 Earth science (SSL= 3.16 percent, $\alpha=0.806)$ all loadings over 0.4

loading

How mountains, rivers and oceans develop and change

0.55

Clouds, rain and the weather

0.50

The inside of the earth

0.49

How people, animals, plants and the environment depend on each other

0.44

The origin and evolution of life on earth

0.42 
Factor 9 Animals (SSL=3.10 percent, $\alpha=0.806$ ) all loadings over 0.4

loading

Animals in other parts of the world

0.71

0.63

0.61

0.50

0.49

0.48

loading

0.58

0.53

0.50

0.46

Cancer, HIV, abortion and first aid are about Health. Black holes, stars, planets and unsolved mysteries in outer space are about Space. The factor with high loading for explosive chemicals, biological and chemical weapons and how the atom bomb functions is called Risk. However, Risk is also connected to an interest in chemical reactions, atoms and molecules. In the same way it is easy to understand the meaning of the factors named Environment, Technology, New Age, Philosophy of Science, Earth Science, Animals and Natural Beauty.

The next step is to see how the factors are correlated to gender (see table 3) and to students' choice of upper secondary programme (see table 4).

Table 3 Factor scores by gender.

Each student has a score for each factor that tells how close that student's answers are connected with this factor. The scores are standardised with a zero mean and a standard deviation of one. (Mean=0 and $S D=1$ ).

\begin{tabular}{|l|c|c|c|}
\hline \multirow{2}{*}{ Factor } & \multicolumn{2}{|c|}{$\begin{array}{c}\text { Mean of the standardised } \\
\text { scores for different factors }\end{array}$} & \multirow{2}{*}{$\begin{array}{c}\text { Difference } \\
\text { girls-boys }\end{array}$} \\
\cline { 2 - 3 } & girls & boys & $0.93^{*}$ \\
\hline Health & 0.48 & -0.46 & $-0.17^{*}$ \\
\hline Space & -0.09 & 0.08 & $-0.75^{*}$ \\
\hline Risk & -0.38 & 0.37 & 0.03 \\
\hline Environment & 0.01 & -0.01 & $-0.59^{*}$ \\
\hline Technology & -0.30 & 0.29 & $0.59^{*}$ \\
\hline New Age & 0.30 & -0.29 & 0.00 \\
\hline Philosophy & 0.00 & 0.00 & $0.23^{*}$ \\
\hline of science & 0.12 & -0.11 & -0.06 \\
\hline Earth science & -0.03 & 0.03 & $0.24^{*}$ \\
\hline Animals & 0.12 & -0.12 & \\
\hline Natural Beauty & & & \\
\hline
\end{tabular}

significant at a 5 percent level. 
There are large differences between girls and boys, especially for Health (nearly 1 SD) and New Age as female factors and Risk and Technology as male factors.

In the questionnaire the students were also asked about their choice of study programme for upper secondary school. There are seventeen different national programmes to choose from and 90 percent of the students had chosen one of those. (The remaining 10 percent of the students had chosen private schools or other programmes.)

Table 4 Factor scores by different upper secondary level choices

\begin{tabular}{|l|c|c|c|c|c|c|}
\hline \multirow{2}{*}{ Factor } & \multicolumn{6}{|c|}{ Mean of the standardised scores for different factors according to choice of different } \\
\cline { 2 - 7 } & Science & Technology & Art & Health Care & $\begin{array}{c}\text { Electrical Engi- } \\
\text { neering }\end{array}$ & $\begin{array}{c}\text { Natural } \\
\text { Resource } \\
\text { Use }\end{array}$ \\
\hline Health & 0.22 & -0.63 & -0.01 & 1.17 & -0.70 & -0.84 \\
\hline Space & 0.19 & 0.24 & -0.07 & -0.04 & -0.11 & -0.59 \\
\hline Risk & 0.51 & 0.43 & -0.31 & -0.52 & 0.04 & -0.61 \\
\hline Environment & 0.08 & -0.15 & 0.25 & -0.07 & 0.04 & 1.49 \\
\hline Technology & -0.01 & 0.30 & -0.02 & -0.46 & 0.65 & -1.00 \\
\hline New Age & -0.08 & -0.19 & 0.64 & 0.11 & -0.57 & -0.72 \\
\hline Philosophy \\
of science
\end{tabular}

Future science students have high scores for several factors and highest for Risk, Earth science and Philosophy of Science. The Art programme connects with New Age, the Health Programme connects with the Health factor, and the Electrical Engineering programme has high scores for Technology and low score for Health and New Age. Natural resource programme has high score for Environment and Animals.

\section{Student's opinion about their science classes}

In the questionnaire there are also questions about the students' science classes. Students are asked if they like school science better than most other subjects and the interest factors are compared with that question. Those students who agree scores 0.74 for Risk, 0.21 for Health and 0.24 for Space. Those who disagree scores - 0.39 for the Risk factor, -0.11 for Health and -0.14 for Space. Those students that like science better than other subject has small positive values for most of the factors, though they like many topics in science. Nevertheless the Risk factor is the factor with strongest connection to school science. 


\section{Discussion}

The ten factors described in this article illustrate ten distinct interest profiles in science among Swedish students. Topics with high loading for each factor are easily connected and the factors are easy to understand. The KMO is 0,951 and this is well over what is required, furthermore Cronbachs alpha coefficients are also high.

\section{Gender}

There are large gender differences in the students' responses. Girls are interested in how to cure diseases, birth control and functions of the human body. The difference between girls' and boys' scores on the Health factor is almost one standard deviation. New Age, which includes thought transference, ghosts and what dreams may mean, is also a typical girls' interest. Earth Science and Natural Beauty are to lesser extent female factors. Boy factors are Technology with interests in technical devices and Risk with interests in explosives, weapons, chemicals and atoms. This is a very traditional gender pattern. Girls are interested in Health whereas boys are interested in Risk. This is also true for most of the previously reported results from the ROSE survey in Sweden (Jidesjö, et al., 2009; Oscarsson, et al., 2009). The results are also in line with Schreiner (2005) with apparent gender patterns for the different interest profiles. It is possible to compare students interested in Health with Schreiner's 'selective girl' with discriminating preferences and interests in traditionally female topics. Similarly, Schreiner's 'selective boy', with interests in school science and in traditionally masculine topics, can be compared with Risk students in this study.

The large gender differences seem to be in contradiction to the fact that Sweden is regarded as one of the most equal countries in the world (Hausmann, et al., 2010). Has nothing changed despite growing gender equality and despite campaigns to increase girls' interest in science? The differences in interests and career ambitions between boys and girls are an expression of the gender rules and regulation that still exist in the identity formation during adolescence. We can compare this with Ambjörnssons (2004) description of the importance of the peer group and how the girls struggle to become a 'proper' girl. Boys are boys, girls are girls, and Butler's (1990) heterosexual matrix is still evident, in contradiction to our apparently emancipated society. Tradition is less important and youths are acting in a market. It is however not a free market. There is no trace of unisex fashion in the clothing stores and many magazines and television shows are orientated to either boys or girls. How does this affect recruitment? The science programme at upper secondary school attracts both boy and girls but it seems to be for different reasons. This is shown by the different path they chose after secondary school (SOU, 2010).

\section{The interest rules}

It is apparent how students own interest govern their choice of upper secondary programme. Future Health care students have high scores in Health and future Electrical engineering students have high scores in Technology. Future Natural resource use students have high scores in Environment and Art students are fascinated by New Age. This is an example of Giddens (1991) description of identity formation and how youth choose their future. For a young boy or girl choosing upper secondary programme today it is not primarily about what to be as a grown up. Instead it is more about who they want to be and what group they feel connected to.

Earth Science and Philosophy of Science are factors that interest future science students. Risk with interests in explosive chemicals, ABC weapons but also in chemicals, atoms and molecules is nevertheless the factor that is most obviously connected with an interest in school science. Future science students are also recruited mostly from the group with high scores in Risk. Factor analysis show that this area of interest is what separates science students from other students. This does not mean that science students find these topics more interesting than other topics. How to exercise to keep the body fit and strong, how it feels to be weightless in space, the possibility of life outside earth and other topics from Health and Space are the most popular even among future science 
students. These topics are also popular among a majority of other students and therefore this is not observable in the factor analysis. Students with high score in Health and Space and low score in Risk could be a potential for recruitment to science. These students' interests are many ways in line with the science curriculum. Hence, if science teachers focus more on combining topics from Risk, Earth Science, and Philosophy of Science with topics from Health and Space, there is a great potential for increasing students' interest in science.

Oscarsson et al. (2009) describes a gap between the science curriculum and the topics that the teachers cover in their science classes. Compulsory school has goals concerning scientific literacy, and an aim that all students shall reach a specified level of general knowledge in science. A new science curriculum is launched in 2011 with even more focus on scientific literacy and the implementation will be a challenge. New national test in the science subjects were introduced in 2009 and they might contribute to bridging the gap between the curriculum and what is taught in Swedish science classrooms.

\section{CONCLUSIONS}

It is striking how the students' interest profiles govern their choice of upper secondary programme. It seems obvious that students' interests must be in the forefront in a discussion about recruitment to upper secondary school. Future science students are interested in a broad spectrum of science topics but it is their interest in spectacular and dangerous phenomena that separates them from other students. The new science curriculum is better in line with the majority of the students' interests and the future will show whether that can change the students' picture of school science and increase their interest of a science career.

\section{REFERENCES}

Ambjörnsson, F. (2004). I en klass för sig : genus, klass och sexualitet bland gymnasietjejer. Stockholm: Ordfront.

Bourdieu, P. (Ed.). (1993). Kultursociologiska texter. Stockholm : B. Östlings bokförlag. Symposion.

Brace, N., Kemp, R., \& Snelgar, R. (2006). SPSS for psychologists : a guide to data analysis using SPSS for Windows (versions 12 and 13). Basingstoke: Palgrave Macmillan.

Butler, J. (1999). Gender trouble : feminism and the subversion of identity. New York : Routledge. Cronbach, L. J. (1990). Essentials of psychological testing. New York: Harper \& Row.

Giddens, A. (1991). Modernity and self-identity : self and society in the late modern age. Cambridge: Polity press.

Gunnarsson, P. (2009). Gymnasielevers inställning till svensk forskning. Retrieved from http:// www.nyteknik.se/nyheter/innovation/forskning_utveckling/article630740.ece

Hausmann, R., Tyson, L. D., \& Zahidi, S. (2010). The Global Gender Gap Report 2010. Retrieved from http://www3.weforum.org/docs/WEF_GenderGap_Report_2010.pdf

Jenkins, E., \& Nelson. (2005). Important but not for me: students' attitudes towards secondary school science in England. Research in Science \& Technological Education, 23(1), 41-57.

Jidesjö, A., Oscarsson, M., Karlsson, K., \& Strömdahl, H. (2009). Science for all or science for some: What Swedish science students want to learn about in secondary science and technology and their opinions on science lessons. NorDiNa, 5(2), 213-229.

Kaiser, H. (1974). An index of factorial simplicity. Psychometrika, 39(1), 31-36.

Lindahl, B. (2003). Lust att lära naturvetenskap och teknik? En longitudinell studie om vägen till gymnasiet. Göteborg: Acta Universitatis Gothoburgensis.

OECD. (2007). PISA 2006: Science Competencies for Tomorrow's World, Vol. 1 Paris: OECD Publications.

Osborne, J., Simon, S., \& Collins, S. (2003). Attitudes towards science: a review of the literature and its implications. International Journal of Science Education, 25(9), 1049-1079. 
Oscarsson, M., \& Jidesjö, A. (2005). Organising The Relevance of Science Education (ROSE) survey in Sweden. Retrieved from http://roseproject.no./network/countries/sweden/sweden. html

Oscarsson, M., Jidesjö, A., Karlsson, K., \& Strömdahl, H. (2009). Science in society or science in school: Swedish secondary teachers' beliefs about science and science lessons compared with what their students want to learn. NorDiNa, 5(1), 18-34.

ROSE-project (2011) The Relevance of Science Education, website retrieved from http://roseproject.no./network/international-partners.html

Schreiner, C. (2005). Exploring a ROSE-garden. Norwegian youth's orientations towards scienceseen as signs of late modernity. University of Oslo, Oslo.

Schreiner, C., \& Sjöberg, S. (2004). Sowing the seeds of ROSE. Oslo: The University of Oslo.

Skolverket. (1994). NOT-häfte 2/1994. Stockholm: Skolverket och högskoleverket.

Skolverket. (1995). NOT-häfte 3/1995. Stockholm: Skolverket och högskoleverket.

Skolverket. (2004). Nationella utvärderingen av grundskolan 2003 : sammanfattande huvudrapport. Stockholm: Statens skolverk.

Skolverket. (2007). Sveriges officiella statistik. Retrieved from http://www.skolverket.se/

Smedler, A., \& Drake, K. (2006). Identitet och kön. In A. Frisén \& P. Hwang (Eds.), Ungdomar och identitet. Stockholm: Natur och kultur.

SOU. (2010). Flickor, pojkar, individer - om betydelsen av jämställdhet för kunskap och utveckling $i$ skolan.

Tabachnick, B. G., \& Fidell, L. S. (2001). Using multivariate statistics. Boston, MA: Allyn and Bacon. 